\title{
Palaeoclimates: the first two billion years
}

\author{
James F. Kasting ${ }^{1, *}$ and Shuhei Ono ${ }^{2}$ \\ ${ }^{1}$ Department of Geosciences, Penn State University, University Park, PA 16802, USA \\ ${ }^{2}$ Geophysical Laboratory, Carnegie Institute of Washington, 5251 Broad Branch Road, NW, Washington, \\ DC 20015, USA
}

\begin{abstract}
Earth's climate during the Archaean remains highly uncertain, as the relevant geologic evidence is sparse and occasionally contradictory. Oxygen isotopes in cherts suggest that between 3.5 and 3.2 Gyr ago $(\mathrm{Ga})$ the Archaean climate was hot $\left(55-85^{\circ} \mathrm{C}\right)$; however, the fact that these cherts have experienced only a modest amount of weathering suggests that the climate was temperate, as today. The presence of diamictites in the Pongola Supergroup and the Witwatersrand Basin of South Africa suggests that by $2.9 \mathrm{Ga}$ the climate was glacial. The Late Archaean was relatively warm; then glaciation (possibly of global extent) reappeared in the Early Palaeoproterozoic, around 2.3-2.4 Ga.

Fitting these climatic constraints with a model requires high concentrations of atmospheric $\mathrm{CO}_{2}$ or $\mathrm{CH}_{4}$, or both. Solar luminosity was $20-25 \%$ lower than today, so elevated greenhouse gas concentrations were needed just to keep the mean surface temperature above freezing. A rise in $\mathrm{O}_{2}$ at approximately $2.4 \mathrm{Ga}$, and a concomitant decrease in $\mathrm{CH}_{4}$, provides a natural explanation for the Palaeoproterozoic glaciations. The Mid-Archaean glaciations may have been caused by a drawdown in $\mathrm{H}_{2}$ and $\mathrm{CH}_{4}$ caused by the origin of bacterial sulphate reduction. More work is needed to test this latter hypothesis.
\end{abstract}

Keywords: palaeoclimate; Precambrian glaciations; methane; greenhouse effect; faint young Sun problem; sulphur isotopes

\section{INTRODUCTION: THE EARLY CLIMATE RECORD}

The first two billion years of Earth's history encompass two geological eons: the Hadean (4.5-3.8 Gyr ago $(\mathrm{Ga})$ ), for which the geologic record is almost nonexistent, and the Archaean (3.8-2.5 Ga), for which a sparse geologic record exists. In addition to those two time periods, this review will cover the Early Palaeoproterozoic Eon as well, as the glaciations that occurred at that time were arguably tied to events that occurred earlier.

The climate of the Hadean is, not surprisingly, extremely poorly understood. The few geologic data that bear on this question include zircons from the Jack Hills region in Western Australia (Wilde et al. 2001; Valley et al. 2002). All these zircons are older than 3.3 Gyr. The cores of some of them are as old as 4.4 Gyr, demonstrating that a solid surface existed by this time. Oxygen isotope ratios in these zircons indicate that these minerals were in contact with liquid water, suggesting that oceans were also present. This conclusion is in agreement with theoretical models of Earth's early evolution (Matsui \& Abe 1986a,b; Zahnle et al. 1988), which predict that the surface should have solidified and oceans should have formed within a few tens of millions of years after the end of the main accretion period. Indeed, oceans may have condensed and been re-vaporized numerous times during the final stages of accretion as the proto-Earth was sporadically

* Author for correspondence (kasting@geosc.psu.edu).

One contribution of 14 to a Discussion Meeting Issue 'Major steps in cell evolution'. impacted by planetesimals that were Moon-sized or larger (Matsui \& Abe 1986a,b; Zahnle et al. 1988).

The mere presence of liquid water at Earth's surface does not provide strong constraints on its surface temperature. For a planet with Earth's current endowment of surface water, $1.4 \times 10^{21} \mathrm{l}$, liquid water can persist at temperatures up to the critical point, $374{ }^{\circ} \mathrm{C}$ (Kasting 1988), or even higher if the effects of salinity are taken into account. A planetary atmosphere acts like a pressure cooker: the total pressure increases with temperature, thereby preventing the oceans from boiling until the surface temperature exceeds the critical temperature.

By the Early Archaean Eon, around 3.2-3.5 Ga, the geologic record provides more concrete, but nonetheless contradictory, constraints. Oxygen isotope ratios in cherts from the Barberton Mountain Land in South Africa suggest that the climate at this time was hot, with a surface temperature of $70 \pm 15^{\circ} \mathrm{C}$ (Knauth \& Lowe 2003). This prediction follows earlier suggestions (Knauth \& Epstein 1976; Karhu \& Epstein 1986) that surface temperatures were high throughout the entire Precambrian; see also Perry \& Lefticariu (2003) for a review. These earlier claims have been largely dismissed by most geologists, as they are inconsistent with the evidence for Precambrian glaciations described below. The usual criticism has been that the oxygen isotope ratios were reset during diagenesis and thus reflect temperatures at depth within sediments, and not the actual surface temperature. Knauth \& Lowe (2003) have addressed this issue. They point out that their isotope data cover a wide range of values and that their estimates for surface temperatures are based on only 
the isotopically heaviest, and thus least altered, values. Ancient carbonates are isotopically lighter as well, by approximately the same amount (Shields \& Veizer 2002), and it seems unlikely that both carbonates and cherts should have had their isotope ratios reset in precisely the same manner.

These isotopic data must, however, be weighed against other evidence that suggests that the Early Archaean climate was more clement. Condie et al. (2001) computed the chemical index of alteration for Precambrian rocks of various ages and concluded that surface temperatures were moderate from approximately 3.5 Ga until 3.0 Ga. Holland (1984) and Sleep \& Hessler (2006) reach similar conclusions about the Early Archaean based on their own palaeoweathering analyses. This suggests that the oxygen isotope data are influenced by some other factor. One possibility is that the oxygen isotope composition of seawater itself has varied over time (Walker \& Lohmann 1989; Shields \& Veizer 2002; Wallmann 2004). The ${ }^{18} \mathrm{O}:{ }^{16} \mathrm{O}$ ratio in seawater is buffered by exchange of oxygen with silicate rocks during circulation through the mid-ocean ridge hydrothermal vents. Muehlenbachs and his colleagues (Muehlenbachs \& Clayton 1976; Holmden \& Muehlenbachs 1993) have argued repeatedly that this process should have maintained a constant ${ }^{18} \mathrm{O}:{ }^{16} \mathrm{O}$ ratio over time. This issue bears continued scrutiny, however, as a systematic bias of this sort would explain all of the anomalously high reported Precambrian surface temperatures. It is also hard to otherwise explain why the oxygen isotopic composition of carbonates should have shifted during the Phanerozoic (Shields \& Veizer 2002), especially as we know that surface temperatures were cool in the Neoproterozoic. Studies of the $\delta^{18} \mathrm{O}$ values of pairs of minerals can, in principle, be used to constrain both temperature and $\delta^{18} \mathrm{O}$ of seawater (Karhu \& Epstein 1986; Perry \& Lefticariu 2003). This approach, however, is still susceptible to later isotope exchange at higher temperature.

The question of Early Archaean and Hadean climate has important consequences for other fields, as it seems likely that life arose sometime between $3.5 \mathrm{Ga}$ (when both microfossils and stromatolites are found) and $\sim 4.2 \mathrm{Ga}$ (the approximate age of the last oceanvaporizing impact; Sleep et al. 1989). For now, the balance of evidence points towards a relatively cool early Earth, or at least to one that was much cooler than implied by the oxygen isotope data.

By $2.9 \mathrm{Ga}$, a stronger argument can be made that Earth's climate was cool. The evidence comes from diamictites of putative glacial origin in the Pongola and Witwatersrand basins of South Africa (Young et al. 1998; Crowell 1999). The 2.8-2.9 Gyr Brooklands Formation in the Belingwe Greenstone Belt in Zimbabwe also contains coarse breccias that could conceivably be glacial (Nisbet et al. 1993), although the authors have interpreted them as formed by debris flows or avalanches. Other forms of glacial evidence (e.g. striations and dropstones) are missing, so this ice age must still be regarded as questionable. Hence, it is listed with a question mark in figure 1 . This cold period coincides with an anomaly in the sulphur isotope record, described in detail below. We will speculate on the connection between these events towards the end of this paper.

The Late Archaean, from 2.7 to $2.5 \mathrm{Ga}$, was again warm, as indicated by the absence of evidence for glaciation. Then, sometime around $2.4 \mathrm{Ga}$, the climate became extremely cold. Unlike the earlier MidArchaean glaciations, these Palaeoproterozoic glaciations are well documented. The evidence for ice exists on at least three continents (North America, Africa and Australia). In North America, three glacial diamictites are found in the Huronian sequence in Southern Canada (Roscoe 1969, 1973; Young 1991). Age constraints bracket the Huronian between 2.2 and $2.45 \mathrm{Ga}$. As pointed out by Roscoe, and later by Walker et al. (1983), these glaciations coincide with the Great Oxidation Event described in this issue by Holland (2006). This correlation is unlikely to have been accidental, and we will offer an explanation in the text that follows. Two glacial layers are found in South Africa (Kopp et al. 2005), at least one of which shows evidence for having formed at low latitudes (Evans et al. 1997). Thus, this may represent a 'Snowball Earth' glaciation similar to the better studied episodes of the Late Proterozoic (Hoffman et al. 1998).

Following the Palaeoproterozoic glaciations, the climate became non-glacial again and remained that way for well over a billion years. This is the time period that Holland (2006) has called 'the boring billion'. To a climatologist, however, this period is not boring; instead, it begs for an explanation, particularly as the Sun remained significantly less bright than today. The evolution of solar luminosity is discussed in $\$ 2$. The question of why the middle Proterozoic was warm, and why it cooled so dramatically around $750 \mathrm{Myr}$ ago (Ma), is fascinating, but it is beyond the scope of this chapter. Pavlov et al. (2003) have suggested that methane was involved; however, their hypothesis relies on a 'Canfield-type' (sulphidic) deep ocean-a scenario that is challenged in Holland's paper. We leave this issue to be sorted out elsewhere.

\section{THEORETICAL CONSIDERATIONS: THE FAINT YOUNG SUN PROBLEM}

The historical record of climate on the early Earth must be considered within the context of solar and planetary evolution. The classic problem of long-term palaeoclimate, first pointed out by Sagan \& Mullen (1972), is that the Sun is thought to have been considerably less luminous early in its history. Figure 2 (from Kasting et al. 1988) shows this predicted change and illustrates its potential effect on Earth's climate. The Sun has brightened more or less linearly with time, starting from an initial luminosity at $4.6 \mathrm{Ga}$ that was approximately $70 \%$ of the present value. This increase is associated with the gradual conversion of hydrogen to helium in the Sun's core, which makes the core denser, and ultimately hotter, over time. The curve shown in the figure is from Gough (1981); surprisingly, the standard solar model has changed little since that time. The two dashed curves represent Earth's effective radiating temperature $\left(T_{\mathrm{e}}\right)$, and its mean global surface temperature $\left(T_{\mathrm{s}}\right) . T_{\mathrm{s}}$ is greater than $T_{\mathrm{e}}$ because of the greenhouse effect of the atmosphere. In this 


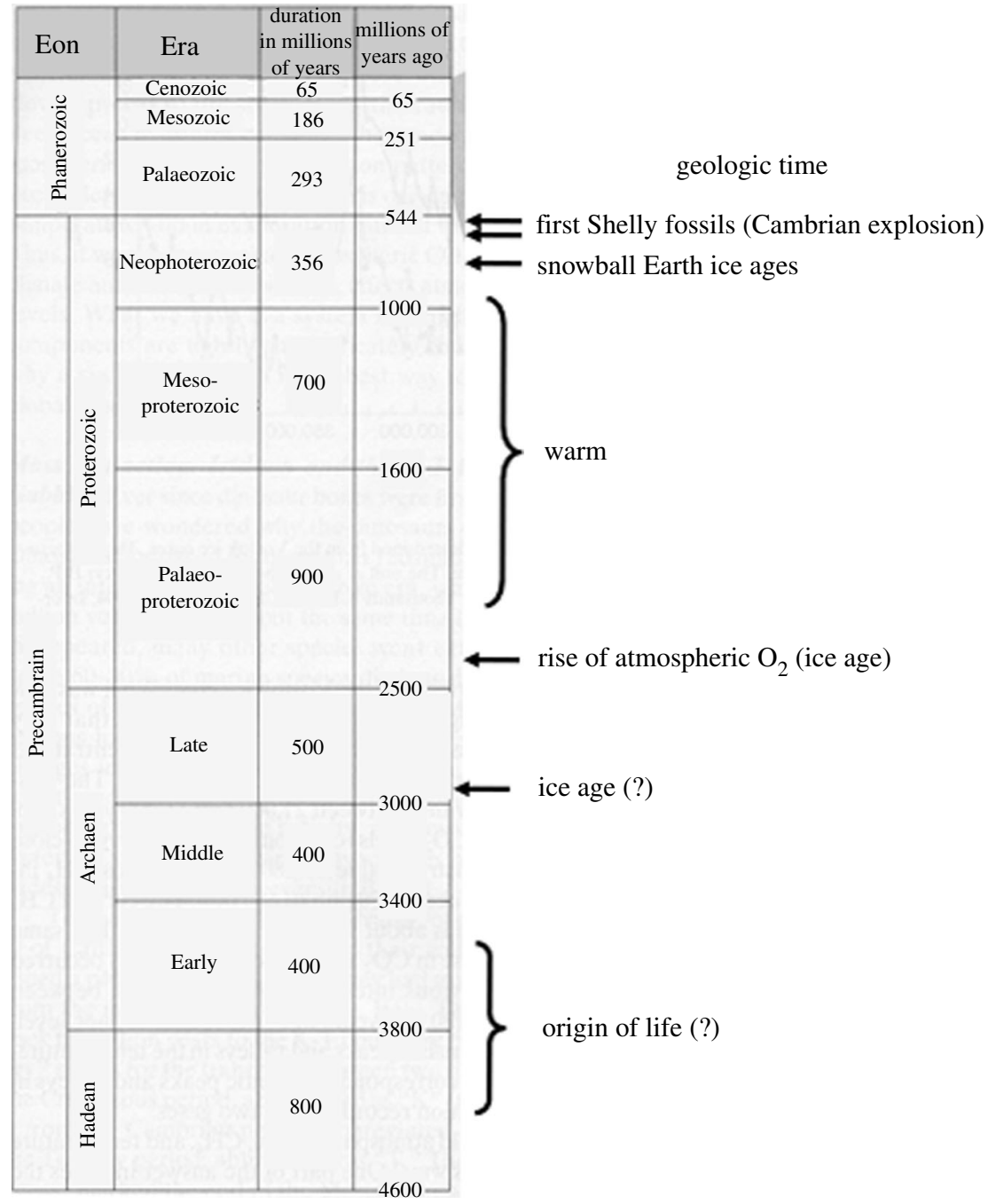

Figure 1. Geologic time-scale showing major climatic and evolutionary events during the Precambrian Era.

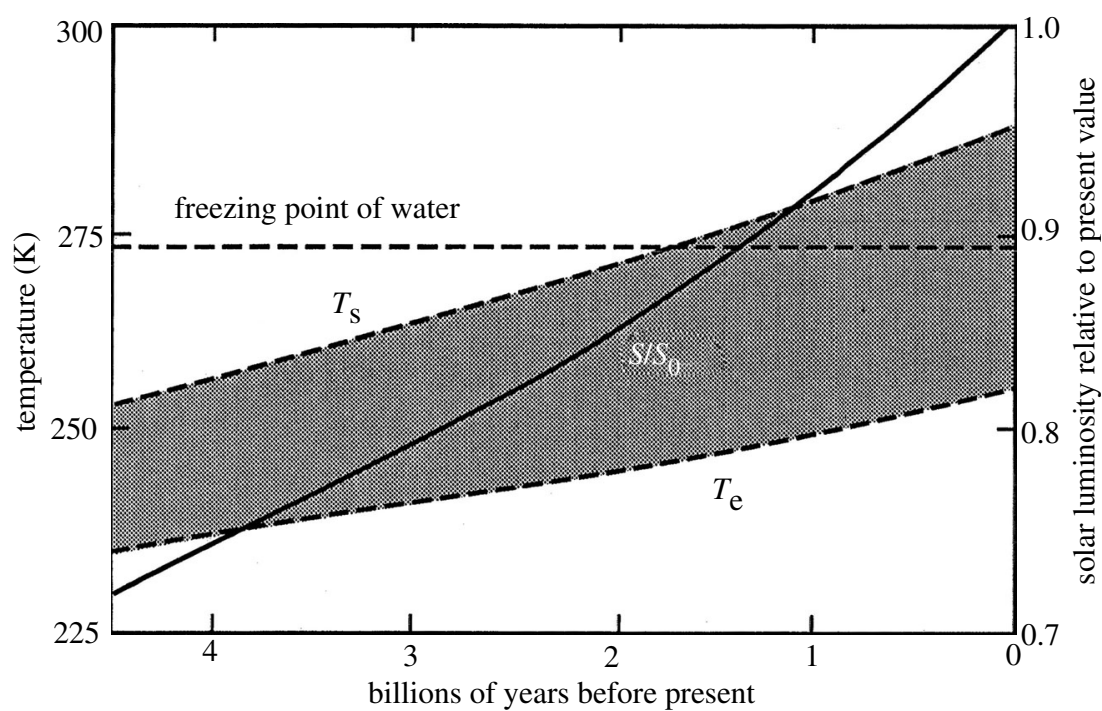

Figure 2. Diagram illustrating the faint young Sun problem. Solid curve represents solar luminosity relative to today. The dashed curves represent Earth's effective radiating temperature $\left(T_{\mathrm{e}}\right)$, and its mean surface temperature $\left(T_{\mathrm{s}}\right)$, as calculated using a onedimensional climate model. Fixed atmospheric $\mathrm{CO}_{2}$ and a fixed relative humidity profile were assumed in the calculation (from Kasting et al. 1988).

calculation, atmospheric $\mathrm{CO}_{2}$ was held constant, and atmospheric $\mathrm{H}_{2} \mathrm{O}$ was allowed to vary by assuming fixed relative humidity. The greenhouse effect increases with time because the $\mathrm{H}_{2} \mathrm{O}$ content of the atmosphere increases as the surface warms. Under these admittedly unrealistic assumptions, Earth's surface would have been frozen during the first half of the planet's history, as originally predicted by Sagan \& Mullen.

A series of papers by various authors has addressed the faint young Sun (FYS) problem; see Kasting (1987, 
1993) for reviews. The most plausible solution is that the atmospheric greenhouse effect was larger in the past. The two gases that seem most likely to have been more abundant are carbon dioxide $\left(\mathrm{CO}_{2}\right)$ and methane $\left(\mathrm{CH}_{4}\right) \cdot \mathrm{H}_{2} \mathrm{O}$, as we saw earlier, provides feedback on climate, but it is not a climate forcer because it is always near its condensation temperature, at least in Earth's atmosphere.

Until 10 or 15 years ago, most papers from this group emphasized $\mathrm{CO}_{2}$ as the dominant greenhouse gas in the early atmosphere (Kasting 1987, 1993). There was a good reason for this: $\mathrm{CO}_{2}$ levels in Earth's atmosphere are expected to respond to changes in climate through the action of the inorganic carbon cycle, also called the carbonate-silicate cycle. $\mathrm{CO}_{2}$ is added to the atmosphere by volcanism. It is removed by weathering of silicate rocks on the continents, followed by precipitation of carbonate sediments in the oceans. Some of the precipitated carbonate is carried down subduction zones, the carbonates are revolatilized, and the cycle begins anew. As pointed out originally by Walker et al. (1981), and as further elaborated on in Berner et al. (1983) and in subsequent papers summarized in Berner (2004), the carbonate-silicate cycle provides a negative feedback on climate: as the climate cools, silicate weathering slows down, and volcanic $\mathrm{CO}_{2}$ accumulates in the atmosphere. The system can only stabilize in the regime where liquid water is present over at least some portion of the planet's surface. Thus, this cycle ensures that Earth's climate remains temperate most of the time. In the few instances when stability falters and Earth's surface becomes covered with ice, the volcanic outgassing side of the carbonate-silicate cycle pumps up atmospheric $\mathrm{CO}_{2}$ to exceedingly high levels and allows the climate system to recover (Kirschvink 1992; Hoffman et al. 1998).

\section{FURTHER COMPLICATIONS: THE INFLUENCE $\mathrm{OF} \mathrm{CH}_{4}$}

Over the past two decades, it has become clear that high $\mathrm{CO}_{2}$ levels may not have provided the entire answer to the FYS problem. It had already been realized more than 20 years ago (Walker 1977; Kasting et al. 1983) that $\mathrm{CH}_{4}$ could have been abundant in the low- $\mathrm{O}_{2}$ Archaean atmosphere. Walker (1987) pointed out that $\mathrm{CH}_{4}$ should have been both mobile and abundant at that time and that the Archaean biosphere could have been 'upside-down', with reduced species in the atmosphere and oxidized iron in sediments. At about this same time, Kiehl \& Dickinson (1987) used a climate model to demonstrate that the greenhouse effect of large amounts of $\mathrm{CH}_{4}$ was significant and that this gas could therefore have played a major role in countering low solar luminosity.

$\mathrm{CH}_{4}$ is destroyed both by photolysis and by reaction with the hydroxyl radical, $\mathrm{OH}$. Hence, in order for it to have been abundant in the early atmosphere, it must have been resupplied by either biotic or abiotic sources. The question of abiotic methane sources received considerable discussion at this meeting. $\mathrm{CH}_{4}$ has been observed in hydrothermal vent fluids emanating from the Lost City ventfield on

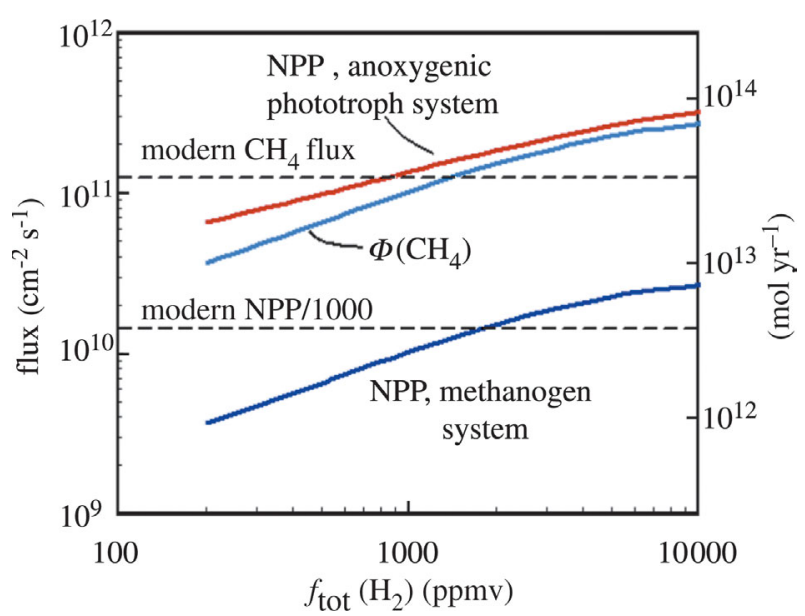

Figure 3. Biogenic methane flux, $\Phi\left(\mathrm{CH}_{4}\right)$, and net primary productivity (NPP) for two different anaerobic ecosystems on the anoxic Archaean Earth. In one ecosystem, autotrophic methanogens dominate primary productivity; in the other, $\mathrm{H}_{2}$-based anoxygenic photosynthesizers dominate. The two systems have different NPP but nearly the same methane flux. The modern biogenic methane flux and marine NPP $(\div 1000)$ are shown for comparison (from Kharecha et al. 2005).

the flanks of the Mid-Atlantic ridge (Kelley et al. 2001, 2005). Kasting \& Catling (2003) estimated a $\mathrm{CH}_{4}$ flux of $1 \times 10^{11} \mathrm{~mol} \mathrm{yr}^{-1}$, or about $1 / 300$ th of the present biological $\mathrm{CH}_{4}$ flux, based on the earlier of these two papers. Kelley et al. (2005) remeasured $\mathrm{CH}_{4}$ concentrations in vent fluids and revised their numbers upward by a factor of 10 . Thus, the abiotic methane source could be as high as $1 \times 10^{12} \mathrm{~mol} \mathrm{yr}^{-1}$. However, questions remain as to whether this methane is truly abiotic or whether it is produced by methanogens living within the hydrothermal vents, as pointed out in this issue by Hayes \& Waldbauer (2006). So, while the present abiotic methane source is uncertain, it is clearly much smaller than the flux of methane that is produced biologically.

Estimating the biological source of methane on the Archaean Earth is a challenging matter because ecosystems then must have been completely different from today. At one extreme, Cavalier-Smith (2006) has argued that methanogens were not even present until much later in Earth history (approx. $1 \mathrm{Ga}$ ). This idea provoked considerable discussion at the meeting. Geologists objected to this hypothesis on several grounds, notably the existence of $2.7 \mathrm{Gyr}$ kerogens with $\delta^{13} \mathrm{C}$ values as low as -50 to $-60 \%$. As discussed by Hayes $(1983,1994)$, production of organic matter with these isotopic characteristics probably requires biological cycling of carbon by methanogens and methanotrophs. Here, we will assume that methanogens were present by $2.7 \mathrm{Gyr}$, and we will postulate that they may have evolved even earlier.

Assuming that methanogens are indeed ancient, various authors have attempted to estimate their effect on early atmospheric composition. Two different approaches have been tried: Kral et al. (1998) and Kasting et al. (2001) used a strictly thermodynamic method based on the amount of free energy needed to drive methanogenic metabolism. This approach allows one to estimate $\mathrm{CH}_{4}: \mathrm{H}_{2}$ ratios, but it says nothing 


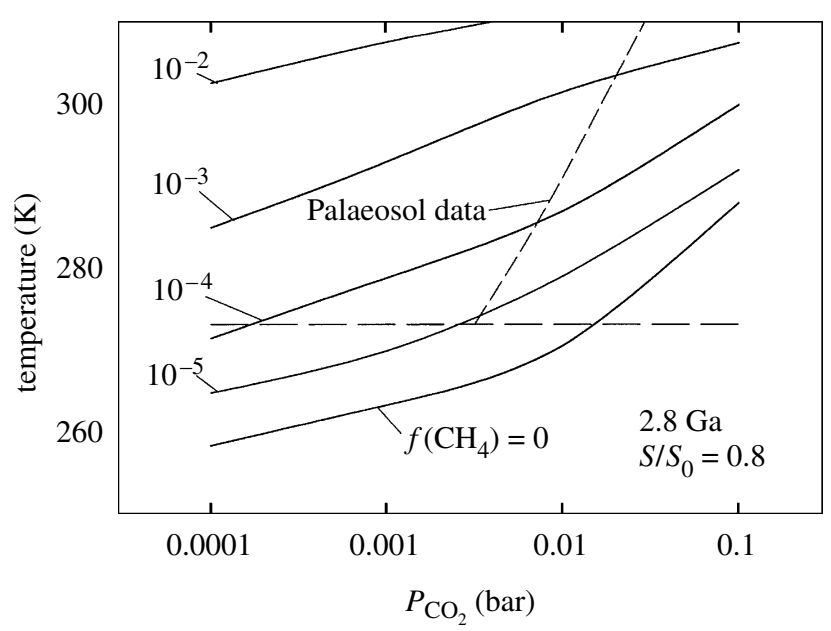

Figure 4. Mean global surface temperature at $2.8 \mathrm{Ga}$ for different $\mathrm{CO}_{2}$ partial pressures and $\mathrm{CH}_{4}$ mixing ratios. The assumed solar flux is $80 \%$ of today's value. The two dashed curves represent the freezing point of water and an upper limit on $P_{\mathrm{CO}_{2}}$ derived from palaeosols (Rye et al. 1995) (from Pavlov et al. 2000).

about $\mathrm{CH}_{4}$ fluxes. More recently, Kharecha et al. (2005) developed a more elaborate thermodynamickinetic model that predicts fluxes and that also accounts for gradients in gas concentrations between the atmosphere and surface ocean. Because of its possible relevance to Archaean climate, this model is described briefly below.

Today, methanogens are restricted to anaerobic environments such as the intestines of cows and the water-logged soils in rice paddies. As shown by Holland (2006), the entire atmosphere should have been anoxic during the Archaean, and so methanogen habitats should have been much more widespread. Rather than being confined to sediments, methanogens could have proliferated in both the surface and deep oceans. There, they would have competed with a variety of other anaerobic organisms, especially anoxygenic photosynthesizers that used $\mathrm{H}_{2}, \mathrm{H}_{2} \mathrm{~S}$, or $\mathrm{Fe}^{++}$as reductants. Methane could have been produced either by autotrophic methanogens that fed on $\mathrm{H}_{2}$ :

$\mathrm{CO}_{2}+4 \mathrm{H}_{2} \rightarrow \mathrm{CH}_{4}+2 \mathrm{H}_{2} \mathrm{O}$

or by methanogens working in concert with fermentative bacteria to degrade the organic matter produced by other mechanisms. For example, if primary production was carried out by $\mathrm{H}_{2}$-based anoxygenic photosynthesizers, a possible reaction sequence would be:

Anoxygenic photosynthesis :

$$
\mathrm{CO}_{2}+2 \mathrm{H}_{2} \rightarrow \mathrm{CH}_{2} \mathrm{O}+\mathrm{H}_{2} \mathrm{O} \quad(\times 2)
$$

Fermentation :

$$
2 \mathrm{CH}_{2} \mathrm{O} \rightarrow \mathrm{CH}_{3} \mathrm{COOH}
$$

Methanogenesis :

$$
\underline{\mathrm{CH}_{3} \mathrm{COOH} \rightarrow \mathrm{CH}_{4}+\mathrm{CO}_{2},}
$$

Net : $\quad \mathrm{CO}_{2}+4 \mathrm{H}_{2} \rightarrow \mathrm{CH}_{4}+2 \mathrm{H}_{2} \mathrm{O}$.

The net effect of reactions (R2)-(R4) is the same as that of (R1).

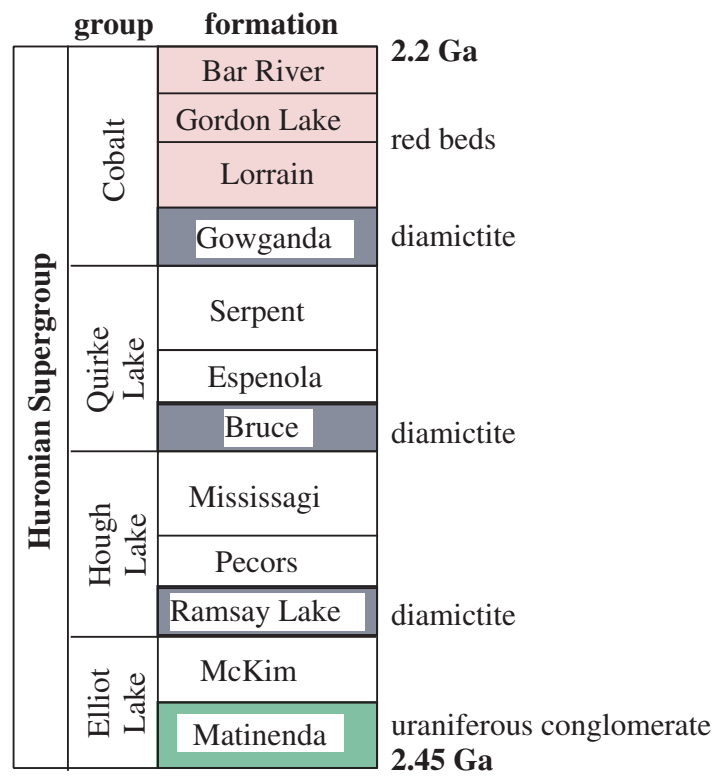

Archean basement

Figure 5. Stratigraphic sequence of the Huronian Supergroup in Southern Canada, showing the three glacial diamictites. Atmospheric $\mathrm{O}_{2}$ levels increased dramatically during this time-interval (see text) (from Young 1991).

Kharecha et al. (2005) have worked out many of the details of this primitive, anoxic ecosystem. $\mathrm{H}_{2}$ emitted by volcanoes should have accumulated in the atmosphere until balanced by loss to space and/or reduction of $\mathrm{CO}_{2}$, followed by burial of organic carbon in sediments. Atmospheric $\mathrm{H}_{2}$ mixing ratios of $10^{-3}$ or more are predicted prior to the origin of methanogens. These estimates are based on a modern $\mathrm{H}_{2}$ outgassing rate of $5 \times 10^{12} \mathrm{~mol} \mathrm{yr}^{-1}$ (Holland 2002). Even higher $\mathrm{H}_{2}$ levels are possible if hydrogen escape to space was slow because of low exospheric temperatures (Tian et al. 2005). Once methanogens evolved, they would have drawn down concentrations of dissolved $\mathrm{H}_{2}$ in the surface ocean to levels set by metabolic thermodynamics. $\mathrm{H}_{2}$ from the atmosphere would have flowed into the ocean to replace it at rates that can be estimated using the 'piston velocity' approach (Broecker \& Peng 1982). The piston velocity is the effective diffusion velocity of a gas through the thin boundary layer at the ocean surface. Numerical values for the piston velocities of various gases are determined empirically by using inert tracers in both wind tunnel experiments and in the actual atmosphere-ocean system. $\mathrm{CH}_{4}$ produced in the surface ocean would have flowed back into the atmosphere at its own piston velocity. There, it would have been converted back into $\mathrm{H}_{2}$ and $\mathrm{CO}_{2}$ (or $\mathrm{CO}$ ) by photolysis and by reaction with hydroxyl $(\mathrm{OH})$ radicals. The detailed photochemistry of $\mathrm{CH}_{4}$ in a low- $\mathrm{O}_{2}$ atmosphere has been studied most recently by Pavlov et al. (2001).

The net result of this analysis is shown in figure 3 . Shown on the graph are the $\mathrm{CH}_{4}$ flux, $\Phi\left(\mathrm{CH}_{4}\right)$, and net primary productivity (NPP) for ecosystems based on methanogenesis and $\mathrm{H}_{2}$-based anoxygenic photosynthesis. Also shown as dashed lines are the modern biological $\mathrm{CH}_{4}$ flux and modern global marine NPP $(\div 1000)$. The horizontal axis, $f_{\text {tot }}\left(\mathrm{H}_{2}\right)$, represents the 
total atmospheric hydrogen mixing ratio in the stratosphere: $f_{\text {tot }}\left(\mathrm{H}_{2}\right)=f\left(\mathrm{H}_{2}\right)+f\left(\mathrm{H}_{2} \mathrm{O}\right)+2 f\left(\mathrm{CH}_{4}\right)+\cdots$. This is the sum of the concentrations of all hydrogen-bearing gases, weighted by the number of $\mathrm{H}$ atoms (or $\mathrm{H}_{2}$ molecules) they contain.

Figure 3 shows two things: (i) Archaean NPP was several orders of magnitude less than modern NPP, in agreement with predictions of other authors (e.g. DesMarais 1998; Canfield 2005). NPP for the anoxygenic photosynthesis-based ecosystem is approximately 20 times higher than that for the methanogenbased ecosystem because fewer $\mathrm{H}_{2}$ molecules are needed per unit of produced biomass. (ii) The predicted $\mathrm{CH}_{4}$ flux is within a factor of 3 of the modern value, regardless of which type of organisms dominated the ecosystem. Indeed, the $\mathrm{CH}_{4}$ fluxes from the two ecosystems are so similar that only one curve is shown in the figure. Methane production was limited by gas transfer rates through the atmosphere-ocean interface, not by details of biology or ecology. This conclusion, of course, rests on the assumption that methanogens were indeed present in the Archaean ecosystem.

The calculation of the methane flux is new, and it has implications for the Early Archaean climate. Detailed photochemical modelling (Pavlov et al. 2001) has shown that the lifetime of $\mathrm{CH}_{4}$ in an anoxic atmosphere is approximately 1000 times longer than today. Hence, the same biological methane flux that produces a $\mathrm{CH}_{4}$ mixing ratio of approximately $1.7 \mathrm{ppmv}$ in today's atmosphere should produce a $\mathrm{CH}_{4}$ mixing ratio of over $1000 \mathrm{ppmv}(0.1 \%)$ in a low$\mathrm{O}_{2}$ Archaean atmosphere. Others (Catling et al. 2001) have shown that the predicted $\mathrm{CH}_{4}$ flux should only have increased once oxygenic photosynthesis evolved. This event occurred sometime before $2.4 \mathrm{Ga}$, and probably by $2.7 \mathrm{Ga}$, based on the evidence from organic biomarkers (Brocks et al. 1999; Summons et al. 1999). Hence, it seems likely that $\mathrm{CH}_{4}$ remained an important constituent of the atmosphere throughout the Archaean and Early Palaeoproterozoic eons.

$\mathrm{CH}_{4}$ concentrations of $1000 \mathrm{ppmv}$ or more should have had a big effect on Archaean climate. This is illustrated in figure 4, which shows calculated mean global surface temperatures (solid curves) at $2.8 \mathrm{Ga}$ for different combinations of atmospheric $\mathrm{CO}_{2}$ and $\mathrm{CH}_{4}$. The solar constant at that time was approximately $80 \%$ of its present value (Gough 1981). The two dashed curves represent the freezing point of water and an upper limit on $P_{\mathrm{CO}_{2}}$ derived from palaeosols (Rye et al. 1995). If the palaeosol data are accepted as a constraint, solutions must lie in the upper left-hand corner of this diagram. The solution is further constrained by the requirement that $f\left(\mathrm{CO}_{2}\right) / f\left(\mathrm{CH}_{4}\right)>1$. If the $\mathrm{CH}_{4}$ concentration was higher than that of $\mathrm{CO}_{2}$, then $\mathrm{CH}_{4}$ would have begun to polymerise, forming organic haze and creating a large anti-greenhouse effect (Pavlov et al. 2001). An atmosphere with $f\left(\mathrm{CH}_{4}\right)=f\left(\mathrm{CO}_{2}\right)=10^{-3}$ would yield a predicted surface temperature roughly equal to the modern value, $288 \mathrm{~K}$. The answer is not unique, however, as the same result could be achieved by an atmosphere containing three times more $\mathrm{CO}_{2}$ and three times less $\mathrm{CH}_{4}$. Additional data are needed if one wishes to further constrain this result.

\section{SULPHUR ISOTOPES AND THEIR IMPLICATIONS FOR ATMOSPHERIC $\mathrm{O}_{2}$}

Because the greenhouse effect may have been augmented by $\mathrm{CH}_{4}$, as well as by $\mathrm{CO}_{2}$, our palaeoclimate story necessarily involves $\mathrm{O}_{2}$. Changes in atmospheric $\mathrm{O}_{2}$ would have affected the photochemical lifetime of $\mathrm{CH}_{4}$, as well as the nature of the ecosystems that produced it. Let us therefore briefly consider the time history of atmospheric $\mathrm{O}_{2}$ and its relationship to the atmospheric sulphur cycle. This will prove critical in the explanations offered below for the causes of Early Precambrian glaciations.

The rise of $\mathrm{O}_{2}$ has been studied by many different workers over the past 50 years. Recent reviews have been given by Holland (1994, 2006), Kasting \& Catling (2003) and Canfield (2005). Briefly, atmospheric $\mathrm{O}_{2}$ concentrations appear to have increased dramatically around $2.4 \mathrm{Ga}$, based on a variety of 'conventional' geologic indicators (e.g. detrital minerals, redbeds, banded iron-formations). Some of these $\mathrm{O}_{2}$ indicators are discussed further below. Very strong evidence for an increase in atmospheric $\mathrm{O}_{2}$ at this time comes from the first large-scale appearance of oxidized (and thus insoluble) manganese in the Kalahari Mn Field of South Africa (Bau et al. 1999; Kirschvink et al. 2000). The most precise data, however, come from an 'unconventional' source, namely, mass-independent fractionation (MIF) of sulphur isotopes. As first pointed out by Farquhar et al. (2000), the sulphur MIF signal is observed in rocks of Archaean and Early Palaeoproterozoic age, but not in younger rocks (see figure 1 in Holland (2006)). Although the precise mechanism by which the MIF signal is created is not known, it has been demonstrated to arise during the photolysis of $\mathrm{SO}_{2}$ under low- $\mathrm{O}_{2}$ conditions (Farquhar et al. 2000, 2001).

Pavlov \& Kasting (2002) have studied this problem with a detailed photochemical model and have derived an upper limit of $10^{-5}$ times the present atmospheric level (PAL) on atmospheric $\mathrm{O}_{2}$ during the time when the MIF signal was present. They argued that the actual $\mathrm{O}_{2}$ concentration at this time was much lower than the value quoted, probably of order $10^{-13}$ PAL. This argument was based on two specific points. (i) At these very low $\mathrm{O}_{2}$ levels, the atmospheric sulphur cycle runs in both directions, i.e. outgassed $\mathrm{SO}_{2}$ can be either oxidized to $\mathrm{H}_{2} \mathrm{SO}_{4}$, or it can be reduced to $\mathrm{H}_{2} \mathrm{~S}$ or $\mathrm{S}_{8}$. Appreciable amounts of sulphur must leave the atmosphere in different chemical forms in order for the MIF signal to be preserved. On the modern Earth, by contrast, virtually all of the outgassed $\mathrm{SO}_{2}$ is oxidized to sulphate, either in the atmosphere or in the surface ocean, so any MIF signal that may have been produced by photochemistry is erased before the sulphur is deposited in sediments.

(ii) The reason that $P_{\mathrm{O}_{2}}$ is so extremely low in the Pavlov \& Kasting 'Archaean atmosphere' model is that their estimated $\mathrm{H}_{2}$ and $\mathrm{CH}_{4}$ concentrations were relatively high (approx. $400 \mathrm{ppmv}$ for $\mathrm{H}_{2}$ and 800 ppmv for $\mathrm{CH}_{4}$ ); see Pavlov et al. (2001) for the details. In these calculations, it was assumed that $\mathrm{H}_{2}$ outgassed from volcanoes was lost predominantly by escape to space at the diffusion-limited rate. $\mathrm{H}_{2}$ outgassing rates, as mentioned earlier, were taken 
from Holland (2002). While these assumptions are not unreasonable, the model could be wrong for several reasons: (i) Recently, Tian et al. (2005) have argued that hydrogen escape on the early Earth would have proceeded at much less than the diffusion limit. This would cause $\mathrm{H}_{2}$ and $\mathrm{CH}_{4}$ levels to be higher, and $\mathrm{O}_{2}$ levels to be even lower, than assumed above. (ii) $\mathrm{H}_{2}$ outgassing rates predicted by other authors (Walker 1977; N. Sleep 2005, personal communication) are about an order of magnitude lower than Holland's values. This could cause $\mathrm{H}_{2}$ and $\mathrm{CH}_{4}$ concentrations to be lower than assumed. (iii) The atmospheric hydrogen budget, or redox budget, on the Archaean Earth should also have been affected by rainout of photochemically produced oxidants and reductants and by subsequent reactions of these species within the oceans (e.g. Kasting \& Brown 1998; Kasting in press). In the Pavlov et al. (2001) model, these terms were considered to be a minor part (approx. 10\%) of the atmospheric hydrogen budget. If $\mathrm{H}_{2}$ outgassing rates were lower than assumed, however, then the rainout terms could have been more important. This will form the basis for the hypothesis offered below for triggering the Mid-Archaean (2.9 Ga) glaciations.

\section{TRIGGERING OF THE PALAEOPROTEROZOIC GLACIATIONS}

With this theoretical background in place, we turn now to the question of what caused the Early Precambrian glaciations. As pointed out earlier, the Palaeoproterozoic glaciations appear to have occurred at approximately the same time that atmospheric $\mathrm{O}_{2}$ concentrations first rose. This is documented most clearly in the Huronian Supergroup of Southern Canada (Fig. 5). The Huronian sequence contains three glacial diamictites. From bottom to top, these are the Ramsey Lake Formation, the Bruce and the Gowganda. Below the Ramsey Lake Formation, one finds the Matinenda Formation, which contains abundant detrital pyrite $\left(\mathrm{FeS}_{2}\right)$ and uraninite $\left(\mathrm{UO}_{2}\right)$. These are reduced minerals that are generally absent from sediments formed in oxidized environments. (For non-geologists, a detrital mineral is one that was eroded from its parent rock and was subsequently transported down streams and rivers and deposited without ever undergoing dissolution.) Small amounts of detrital uraninite are found today in the deltas of fast-flowing rivers that drain the Himalayas, but in general such minerals have not been preserved during the latter half of Earth's history.

Above the uppermost glacial layer, one finds the Lorraine redbed. A redbed is a sandstone in which the quartz grains are coated with small specks of hematite $\left(\mathrm{Fe}_{2} \mathrm{O}_{3}\right)$. Hematite contains oxidized, or ferric, iron $\left(\mathrm{Fe}^{3+}\right)$. By comparison, most igneous rocks contain ferrous iron $\left(\mathrm{Fe}^{2+}\right)$, often combined with silicates. If the hematite in the redbed formed by subaerial oxidation, as is generally assumed, then the atmosphere must have been $\mathrm{O}_{2}$-rich when the Lorraine Formation was deposited. This is what led Roscoe $(1969,1973)$ to point out that these glaciations coincided with the rise of atmospheric oxygen.
If the methane greenhouse story told in $\$ 4$ is correct, then the Huronian glaciations are a natural consequence of the observed $\mathrm{O}_{2}$ rise. Such an event would have shortened the photochemical lifetime of $\mathrm{CH}_{4}$, thereby causing its concentration to drop dramatically. According to figure 4, a drop in $f\left(\mathrm{CH}_{4}\right)$ from $10^{-3}$ to, say, $10^{-5}$ should have caused a surface temperature decrease of approximately $20{ }^{\circ} \mathrm{C}$. Unless the climate was exceedingly warm prior to $2.4 \mathrm{Ga}$, this would have been more than enough to trigger glaciation.

Based on this discussion, the identification of $\mathrm{O}_{2}$ rise and $\mathrm{CH}_{4}$ decline as the fundamental cause of the Palaeoproterozoic glaciations appears to be a tenable hypothesis. However, the detailed sequence of events at the time of the Palaeoproterozoic glaciations remains unclear. Why were there at least three distinct glaciations, and did $\mathrm{O}_{2}$ and $\mathrm{CH}_{4}$ levels oscillate up and down during this time-interval? Correlating glacial events on different continents is difficult because strata that carry Palaeoproterozoic glaciations are poorly dated. Bekker et al. (2001) suggest that the Rooihoogte and Timeball Hill formations in South Africa coincide with the second and third of the Huronian glaciations. Some glaciations in Canada and South Africa, however, may not necessarily correlate at all: only one glaciation (the Makganyene) in South Africa has been demonstrated to be global (Evans et al. 1997), whereas reliable palaeolatitude data are missing from the Huronian (Hilburn et al. 2005). Thus, Kopp et al. (2005) argue that all three Huronian glaciations precede the 'snowball' Makganyene glaciation in South Africa.

If one follows Roscoe's $(1969,1973)$ model that the Huronian Supergroup was deposited during the rise of atmospheric $\mathrm{O}_{2}$, one may expect to see the disappearance of sulphur MIF signatures somewhere between the Matinenda and the Lorrain Formations of the Huronian Supergroup (figure 5). Available data for sulphur isotopes suggest, however, that a change in sulphur chemistry appears to pre-date glacial events: the $\Delta^{33} \mathrm{~S}$ values are small (less than $\pm 0.4 \%$ ) for the Huronian Supergroup in Canada (Farquhar et al. 2000; Wing et al. 2002) and the Timeball Hill and the Rooihoogte formations in South Africa (Bekker et al. 2004). This small range of $\Delta^{33} \mathrm{~S}$ values contrasts with the large $\Delta^{33} \mathrm{~S}$ values ( -2.5 to $8.2 \%$ ) for older rock formations (figure 6; Farquhar et al. 2000; Mojzsis et al. 2003; Ono et al. 2003). Farquhar \& Wing (2003) offer two possible explanations for the small, but measurable, sulphur MIF signatures during this time-interval, $2.2-2.45 \mathrm{Ga}$. One is recycling of mass independently fractionated Archaean sulphide. This would imply that the oxygen level rose dramatically at approximately $2450 \mathrm{Ma}$ to allow oxidative weathering of continental sulphide, and also triggering the collapse of a $\mathrm{CH}_{4}$-rich atmosphere at this time. The second possibility is that between 2.2 and $2.45 \mathrm{Ga}$, atmospheric $\mathrm{O}_{2}$ levels rose to intermediate levels that allowed penetration of UV to the troposphere but that still ensured that most atmospheric sulphur was oxidized to $\mathrm{H}_{2} \mathrm{SO}_{4}$. This condition is possible if $P_{\mathrm{O}_{2}}$ was between $10^{-2}$ and $10^{-5}$ PAL. The upper limit $\left(10^{-2}\right.$ PAL) is consistent with that given by the preservation of detrital uraninite at the base of the Huronian Supergroup (Holland 1984). 


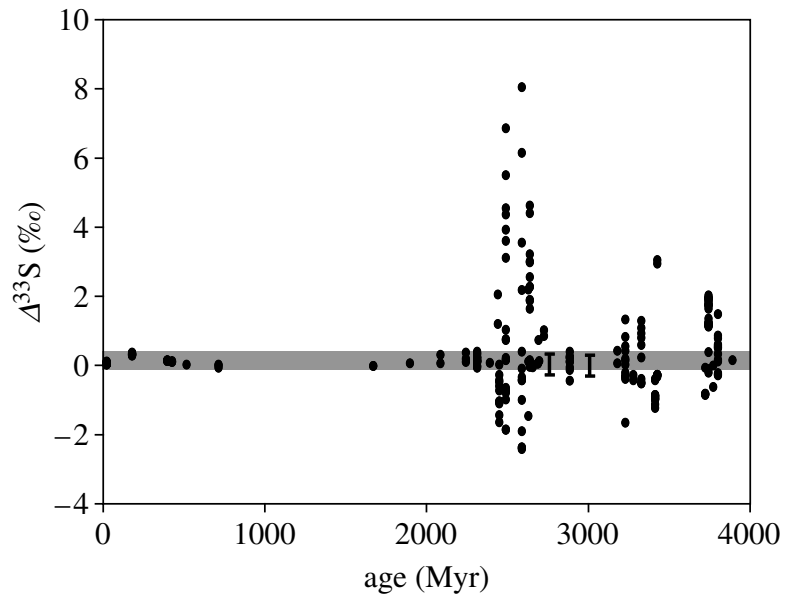

Figure 6. Compilation of $\Delta^{33} \mathrm{~S}$ versus time from rocks of all ages. Most of the data are from Ono et al. (submitted) and references therein. The error bars at 2.8 and 3.0 Gyr bracket the data from the Hardey and Mosquito Creek formations in Western Australia (Watanabe et al. 2005).

Detailed photochemical model studies may tell if fluctuating oxygen levels between $10^{-2}$ and $10^{-5}$ PAL could have triggered multiple glacial events by destabilizing a $\mathrm{CH}_{4}$-rich atmosphere.

\section{POSSIBLE CAUSE OF THE MID-ARCHAEAN GLACIATIONS}

The latest wrinkle in the Precambrian glaciation story is that the putative Mid-Archaean glaciation appears now to be correlated with a second anomaly in the sulphur MIF record. An updated view of the most recent MIF data is shown in figure 6 . As seen in the figure, new data collected from the time period between 2.8 and $3.0 \mathrm{Ga}$ show low MIF signals, $\Delta^{33} \mathrm{~S} \leq 0.5 \%$. The data come from two sources: (i) Watanabe et al. (2005) have analysed pyrite samples from the 2.76 Gyr Hardey Formation and the 3.0 Gyr Mosquito Creek Formation in Australia. (ii) Ono et al. (in press) have analysed samples from the $2.9 \mathrm{Gyr}$ Pongola Formation in South Africa. Both groups argue that the pyrites they have analysed are not detrital. This is critical, as detrital pyrites would be expected to have low MIF values regardless of what was happening in the atmosphere.

The fact that low-MIF sulphur isotope values and the evidence for glaciation coincide temporally, as they do in the Palaeoproterozoic, suggests a causal connection. One possibility is that atmospheric $\mathrm{O}_{2}$ levels actually rose twice: once at around $2.8-3.0 \mathrm{Ga}$ and again at $2.4 \mathrm{Ga}$. If $\mathrm{CH}_{4}$ was an important atmospheric constituent prior to $3.0 \mathrm{Ga}$, then $\mathrm{CH}_{4}$ drawdown could be invoked as the cause of the Mid-Archaean glaciations, similar to the hypothesis presented above for the Palaeoproterozoic glaciations. Such a model would necessarily demand an explanation for why atmospheric $\mathrm{O}_{2}$ concentrations went down again at approximately $2.7 \mathrm{Ga}$. We will not attempt to offer one here. This hypothesis also runs into other difficulties. The Witwatersrand Basin in South Africa, which was formed at approximately the same time as the Pongola Basin and in which one of the putative Mid-Archaean diamictites is found, also contains detrital uraninite and pyrite (Holland 1984, p. 315). Hence, if increased $\mathrm{O}_{2}$ was indeed the cause for this glaciation, the increase must have been small enough so that it did not preclude the preservation of reduced detrital minerals. This constraint may be possible to satisfy, as the sulphur MIF signal disappears somewhere at or below $10^{-5}$ PAL of $\mathrm{O}_{2}$ (see above), whereas detrital pyrite and uraninite disappear at a somewhat high $\mathrm{O}_{2}$ level, perhaps $10^{-4}$ PAL (Holland 1984). The dissolution kinetics of uraninite depend on $\mathrm{CO}_{2}$ concentrations as well; however, it is probably still safe to assume that one could identify an atmospheric $\mathrm{O}_{2}$ level at which sulphur MIF would be absent and yet detrital pyrite and uraninite would still be present.

This leads to yet another question, though: How could atmospheric $\mathrm{O}_{2}$ have been stabilized at such a low level? The prevailing theory for what controls the anoxic-oxic transition (Walker 1977; Walker et al. 1983; Kasting 1993; Catling et al. 2001) is that atmospheric $\mathrm{O}_{2}$ levels rose when the net source for $\mathrm{O}_{2}$ from photosynthesis followed by organic carbon burial overwhelmed the sink for $\mathrm{O}_{2}$ from reaction with reduced volcanic (and metamorphic) gases. $\mathrm{O}_{2}$ levels then increased until oxidation of surface minerals could provide an additional sink. Today, surface oxidation accounts for approximately $80 \%$ of the net sink for $\mathrm{O}_{2}$, according to Holland (1984, 2002). At $2.8 \mathrm{Ga}$, however, we have just seen that detrital pyrite and uraninite were being preserved, rather than oxidized. This hypothesis is thus internally inconsistent. Either our understanding of the early $\mathrm{O}_{2}$ budget is wrong, or the link between sulphur MIF values, atmospheric $\mathrm{O}_{2}$ and glaciation is more complicated that we have assumed.

We suggest here that some combination of these factors may be involved. A possible solution to this problem is suggested by some calculations published almost 25 years ago by Kasting \& Walker (1981) and elaborated on later by Walker et al. (1983). Figure $7 a$, taken from an earlier paper, represents a typical prebiotic, or pre-photosynthetic, atmosphere. $\mathrm{H}_{2}$ is well mixed in this atmosphere and has a mixing ratio of approximately $2 \times 10^{-5}$. Its concentration in this model is determined by the balance between volcanic outgassing and escape to space, as described earlier in this paper. The estimated $\mathrm{H}_{2}$ mixing ratio is lower than value of approximately $10^{-3}$ favoured in more recent models, e.g. Kasting (1993), because the assumed outgassing rate of reduced gases (from Walker (1977)) was lower than the rates favoured by Holland (1984, 2002). The surface $\mathrm{O}_{2}$ mixing ratio in this model was approximately $2 \times 10^{-14} \mathrm{PAL}$, in rough agreement with that in Pavlov et al. (2001) and Pavlov \& Kasting (2002). Although these particular calculations did not include sulphur gases, such an atmosphere should have produced a substantial sulphur MIF signal.

Figure $7 b$ shows what would happen in this model if outgassing of hydrogen was shut off for some reason. $\mathrm{H}_{2}$ is poorly mixed in such an atmosphere. Its surface mixing ratio drops below $10^{-8}$, while the $\mathrm{O}_{2}$ surface mixing ratio increases to $4 \times 10^{-8} \mathrm{PAL}$. Such an atmosphere might or might not produce a sulphur MIF signal. The relevant photochemical calculations have not yet been done. Walker et al. (1983) suggest a 

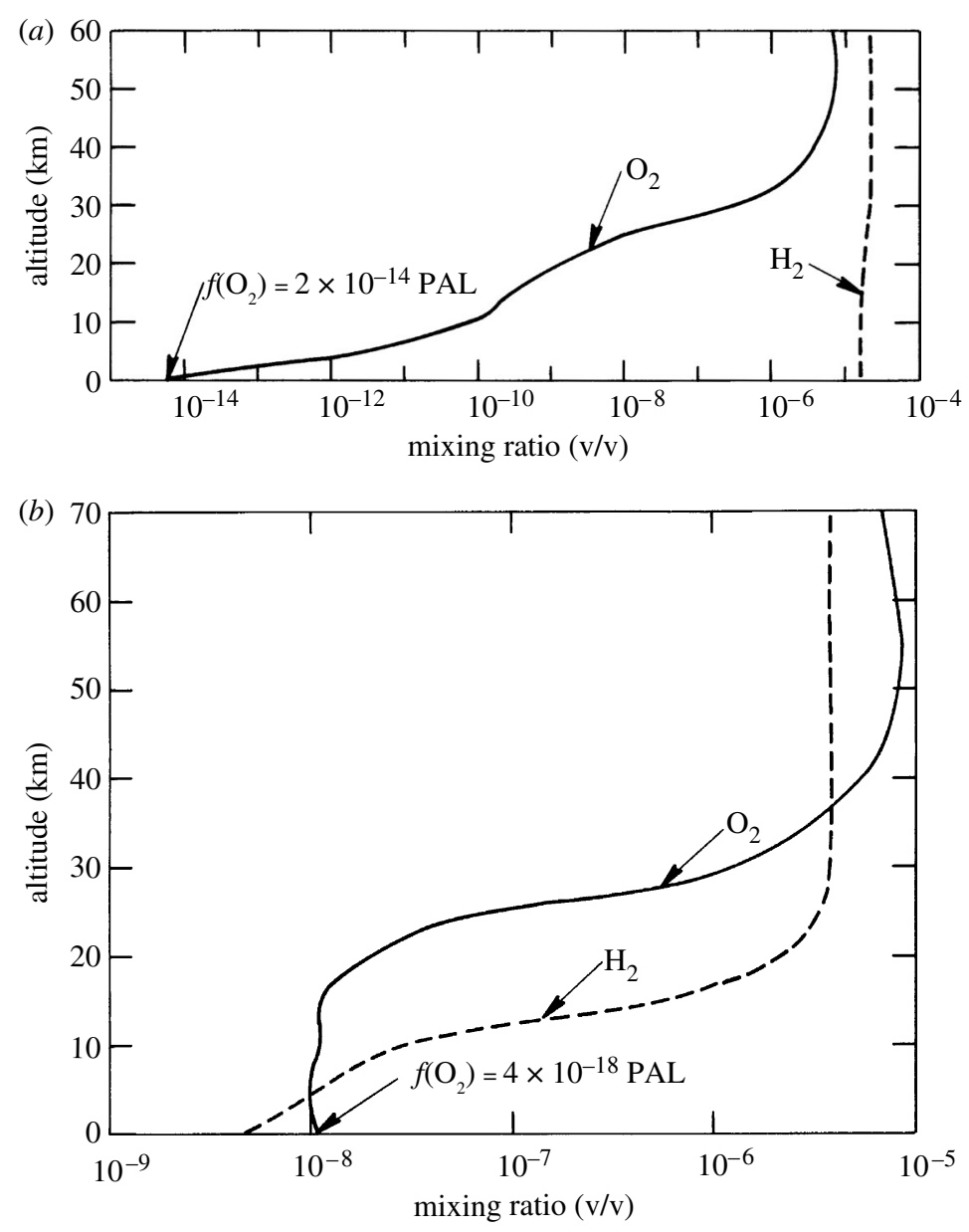

Figure 7. (a) 'Case 1' atmosphere from Kasting \& Walker (1981). Volcanic outgassing of $\mathrm{H}_{2}$ is balanced by escape to space. (b) 'Case 2' atmosphere from the same paper. No volcanic outgassing. Escape of $\mathrm{H}_{2}$ to space is balanced by flow of $\mathrm{O}_{2}$ from the atmosphere into the ocean.

third possible steady state, in which loss of $\mathrm{O}_{2}$ was limited by the transfer rate to the deep ocean and in which atmospheric $\mathrm{O}_{2}$ built-up to approximately $10^{-5}$ PAL. This type of solution clearly would eliminate the sulphur MIF signal. Both of these latter solutions still represent possible pre-photosynthetic atmospheres: no biological production of $\mathrm{O}_{2}$ is assumed. This hypothesis contrasts with that of Ono et al. (submitted) who pursue a similar idea, but who attribute the $2.9 \mathrm{Ga} \mathrm{O}_{2}$ rise to the origin of oxygenic photosynthesis. Could a stable atmosphere with a modest, but non-negligible $\mathrm{O}_{2}$ level have prevailed from 2.8 to $3.0 \mathrm{Ga}$ ?

The situation simulated in these earlier models is physically unrealistic: there is no plausible reason why volcanic outgassing should have ceased for such an extended period of time. The redox balance assumed in figure $7 b$ may also be incorrect. In that simulation, hydrogen escape to space was balanced by $\mathrm{O}_{2}$ uptake by the oceans. $\mathrm{O}_{2}$ was assumed to flow into the ocean at its piston velocity of approximately $5 \mathrm{~m} \mathrm{~d}^{-1}$ (Broecker $\&$ Peng 1982). Once in the ocean, $\mathrm{O}_{2}$ was assumed to have been consumed by reaction with dissolved ferrous iron.

As mentioned earlier, subsequent modelling (e.g. Kasting et al. 1984; Kasting \& Brown 1998) has shown that rainout of photochemically produced oxidants and reductants is also important in the atmospheric redox balance. Indeed, rainout of oxidants such as $\mathrm{H}_{2} \mathrm{O}_{2}$ and $\mathrm{H}_{2} \mathrm{SO}_{4}$ becomes significant at atmospheric $\mathrm{O}_{2}$ levels that are substantially lower than those shown in figure $7 b$. When these terms are included in the redox budget, atmospheric $\mathrm{H}_{2}$ levels never fall as low as those shown in figure $7 b$, even when volcanic outgassing is 'turned off' (e.g. Kasting et al. 1984). This suggests that physically realistic solutions may exist that have the same general nature as those shown in figure $7 b$ but in which the rainout terms in the hydrogen budget are comparable to rates of $\mathrm{H}_{2}$ outgassing and escape. High atmospheric $\mathrm{O}_{2}$ levels would be favoured if the loss of photochemically produced oxidants was limited by transfer from the surface ocean to the deep ocean, as suggested by Walker et al. (1983).

To be more quantitative about these hypotheses, we can write the atmospheric redox balance as (Kasting \& Brown 1998; Kasting in press)

$\Phi_{\text {out }}\left(\mathrm{H}_{2}\right)+\Phi_{\text {rain }}(\mathrm{Ox})=\Phi_{\text {esc }}\left(\mathrm{H}_{2}\right)+\Phi_{\text {rain }}(\mathrm{Red})$

Here, $\Phi_{\text {out }}\left(\mathrm{H}_{2}\right)$ represents volcanic outgassing of $\mathrm{H}_{2}$ and other reduced gases, weighted by their stoichiometric coefficients in the redox budget, $\Phi_{\text {esc }}\left(\mathrm{H}_{2}\right)$ represents escape to space and $\Phi_{\text {rain }}(\mathrm{Ox})$ and $\Phi_{\text {rain }}(\mathrm{Red})$ represent, respectively, the rainout rates of oxidants and reductants. All redox reactions are expressed relative to the 'neutral' species: $\mathrm{H}_{2} \mathrm{O}, \mathrm{CO}_{2}, \mathrm{~N}_{2}$ and $\mathrm{SO}_{2}$. For example, production of hydrogen peroxide $\left(\mathrm{H}_{2} \mathrm{O}_{2}\right)$ from 
$\mathrm{H}_{2} \mathrm{O}$ photolysis can be written as:

$2 \mathrm{H}_{2} \mathrm{O} \rightarrow \mathrm{H}_{2} \mathrm{O}_{2}+\mathrm{H}_{2}$.

Hence, rainout of one mole of $\mathrm{H}_{2} \mathrm{O}_{2}$ leaves behind one mole of $\mathrm{H}_{2}$ in the atmosphere. The coefficient of $\mathrm{H}_{2} \mathrm{O}_{2}$ in the redox budget is thus -1 . Conversely, rainout of formaldehyde is a sink for $\mathrm{H}_{2}$ because the overall reaction can be written as:

$\mathrm{CO}_{2}+2 \mathrm{H}_{2} \rightarrow \mathrm{H}_{2} \mathrm{CO}+\mathrm{H}_{2} \mathrm{O}$.

The coefficient of $\mathrm{H}_{2} \mathrm{CO}$ in the redox budget is thus +2 .

In order to proceed further, we must make a small extension to previously published work. Equation (6.1) has previously described as applying to the atmosphere by itself (e.g. Kasting \& Brown 1998). As pointed out by Kharecha et al. (2005), that description is incorrect or at least incomplete. The atmosphere and the ocean are in close contact with each other, and so one should really apply the concept of redox balance to the combined atmosphere-ocean system. Rainout of oxidants into the ocean is a source of $\mathrm{H}_{2}$ only if the oxidants are consumed by reaction with reduced species such as $\mathrm{Fe}^{2+}$. Rainout of reductants is a sink for $\mathrm{H}_{2}$ only if they are prevented from being remobilized and re-entering the atmosphere. For example, on the pre-biotic Earth formaldehyde may have been consumed by polymerization to sugars via the Cannizzaro reaction followed by burial in sediments (Pinto et al. 1980). In this case, rainout of formaldehyde would be a sink for $\mathrm{H}_{2}$. Alternatively, formaldehyde could have been decomposed by fermentation and methanogenesis (reactions (R3) and (R4)). In this second case, rainout of formaldehyde would be redox-neutral because its reducing power would re-emerge in the form of $\mathrm{CH}_{4}$.

Let us now apply this methodology to the problem at hand. Our specific hypothesis for the cause of the $2.9 \mathrm{Ga}$ glaciations is inspired by a recent paper by Huston \& Logan (2004). These authors point out that bedded sulphates are absent from the geologic record between 3.2 and $2.4 \mathrm{Ga}$. Prior to $3.2 \mathrm{Ga}$, one finds barite $\left(\mathrm{BaSO}_{4}\right)$ deposits. Barite is an extremely insoluble mineral and, hence, could have formed at low oceanic sulphate concentrations. The authors suggest, following Kasting et al. (1989) and Pavlov \& Kasting (2002), that these small amounts of sulphate could have been produced photochemically from photolysis of $\mathrm{SO}_{2}$. Disproportionation of sulphite and bisulphite in the oceans might also have produced sulphate. At $3.2 \mathrm{Ga}$, according to the authors, biological sulphate reduction evolved, and the sulphate reducers swept the oceans almost completely free of sulphate. Then, at $2.4 \mathrm{Ga}$, atmospheric $\mathrm{O}_{2}$ levels increased, sulphate became much more abundant in the oceans, and gypsum $\left(\mathrm{CaSO}_{4} \cdot 2 \mathrm{H}_{2} \mathrm{O}\right)$ appeared for the first time in the geologic record.

It must be acknowledged that this hypothesis is in disagreement with the conclusions of Shen et al. (2001); see also Shen \& Buick (2004). These authors analysed the sulphur isotopic composition of coexisting sulphides and sulphates (barite) at $3.5 \mathrm{Ga}$ and concluded that biological sulphate reduction had already evolved at that time. This result could be reconciled with the theory presented here if these early sulphate reducers were hyperthermophiles, as the most deeply branching sulphate reducers appear to be. However, analysis of the interfacial angles of the barites suggests that they were deposited initially as gypsum, which is only stable at temperatures below $60{ }^{\circ} \mathrm{C}$ (Shen et al. 2001). If this is correct, then mesophilic sulphate reducers had already evolved by $3.5 \mathrm{Ga}$, and the Huston \& Logan idea would have to be modified or abandoned. We explore it here anyway as one example of how the sulphur MIF data might be explained.

Consider now how the evolution of bacterial sulphate reduction (BSR) might have affected the redox budget (equation (6.1)). Prior to the origin of this metabolism, sulphate produced in the atmosphere or in the oceans should have been consumed by reaction with reduced minerals in the seafloor. This happens today within hydrothermal vents. It is, indeed, the dominant mechanism by which the modern seafloor is oxidized (Lecuyer \& Ricard 1999). If one starts from outgassed $\mathrm{SO}_{2}$, one can write the reaction sequence as:

$$
\begin{aligned}
& \mathrm{SO}_{2}+2 \mathrm{H}_{2} \mathrm{O} \rightarrow \mathrm{H}_{2} \mathrm{SO}_{4}+\mathrm{H}_{2} \quad(\times 2), \\
& 2 \mathrm{H}_{2} \mathrm{SO}_{4}+15^{\circ} \mathrm{FeO}^{\prime} \rightarrow 7 \mathrm{Fe}_{2} \mathrm{O}_{3}+\mathrm{FeS}_{2}+2 \mathrm{H}_{2} \mathrm{O},
\end{aligned}
$$

Net :

$$
2 \mathrm{SO}_{2}+15^{\circ} \mathrm{FeO}{ }^{\prime}+2 \mathrm{H}_{2} \mathrm{O} \rightarrow 7 \mathrm{Fe}_{2} \mathrm{O}_{3}+\mathrm{FeS}_{2}+2 \mathrm{H}_{2} \text {. }
$$

By looking at the overall reaction (R9), one can see that because sulphate was being used to oxidize iron, outgassed $\mathrm{SO}_{2}$ should have been a net source of $\mathrm{H}_{2}$ prior to the origin of BSR. This reaction sequence should therefore have tended to increase the $\mathrm{H}_{2}$ content of the atmosphere. If methanogens were present at this time (before $3.2 \mathrm{Ga}$ ), they should have converted much of this $\mathrm{H}_{2}$ to $\mathrm{CH}_{4}$, and this $\mathrm{CH}_{4}$ may in turn have helped to keep the climate warm.

Now, consider how the sulphur cycle would have changed once BSR had evolved. In this case, most of the sulphate produced in the oceans should have been consumed by reaction with organic matter. Sulphite may have been similarly consumed (Skyring \& Donnelly 1982). In the case of sulphate reduction, the overall sequence can be written as:

$$
\begin{aligned}
& \mathrm{SO}_{2}+2 \mathrm{H}_{2} \mathrm{O} \rightarrow \mathrm{H}_{2} \mathrm{SO} 4+\mathrm{H}_{2} \quad(\times 2), \\
& 2 \mathrm{H}_{2} \mathrm{SO}_{4}+\mathrm{FeO}+7 / 2 \mathrm{CH}_{2} \mathrm{O} \rightarrow \mathrm{FeS}_{2} \\
& \quad+7 / 2 \mathrm{CO}_{2}+11 / 2 \mathrm{H}_{2} \mathrm{O} \\
& \quad 7 / 2 \mathrm{CO}_{2}+7 \mathrm{H}_{2} \rightarrow 7 / 2 \mathrm{CH}_{2} \mathrm{O}+7 / 2 \mathrm{H}_{2} \mathrm{O},
\end{aligned}
$$

Net : $\quad 2 \mathrm{SO}_{2}+\mathrm{FeO}+5 \mathrm{H}_{2} \rightarrow \mathrm{FeS}_{2}+5 \mathrm{H}_{2} \mathrm{O}$.

Sulphite reduction would yield the same net stoichiometry. Outgassed $\mathrm{SO}_{2}$ would in this case be a sink for $\mathrm{H}_{2}$ because the sulphur would be reduced to pyrite, and no oxidation of iron would occur. The sulphur cycle would thus have drawn down atmospheric $\mathrm{H}_{2}$ concentrations, and possibly $\mathrm{CH}_{4}$ concentrations as well, cooling the climate and possibly triggering glaciation. This sequence of events is generally 
consistent with what may have happened at that time in Earth history.

Whether or not the scenario proposed above is correct remains to be determined. Photochemical modelling calculations need to be performed to see whether it is actually plausible to influence atmospheric $\mathrm{H}_{2}$ concentrations by the mechanism described here. Such modelling cannot be strictly rigorous until the precise mechanisms responsible for creating sulphur MIF are discovered. The timing of events is also critical. If Huston \& Logan are correct and BSR was invented at $3.2 \mathrm{Ga}$, why did the glaciations occur at approximately $2.9 \mathrm{Ga}$ ? When exactly did the sulphur MIF values drop to near zero, and is this signal recorded in all of the sulphur-bearing sediments deposited at that time? All these questions remain to be answered before any detailed conclusions can be drawn. The scenario described here is not intended to be definitive; rather, we hope that it will stimulate thinking about processes that might have been important during the Mid-Archaean. Eventually, through a combination of modelling and data acquisition, we can hope to gain an improved understanding of how atmospheric composition, climate and the biota coevolved during this early part of Earth's history.

J.F.K. thanks the NASA Exobiology and Astrobiology programmes for funding. S.O. thanks the Agouron Institute and the Carnegie Institution of Washington for funding. The authors thank Euan Nisbet and an unnamed reviewer for their helpful comments that have improved this manuscript. Thanks also to Dick Holland for early access to his manuscript for this special issue.

\section{REFERENCES}

Bau, M., Romer, R. L., Lüders, V. \& Beukes, N. J. 1999 Pb, $\mathrm{O}$, and $\mathrm{C}$ isotopes in silicified Mooidraai dolomite (Transvaal Supergroup, South Africa): implications for the composition of Paleoproterozoic seawater and 'dating' the increase in oxygen in the Precambrian atmosphere. Earth Planet. Sci. Lett. 174, 43-57. (doi:10.1016/S0012821X(99)00261-7)

Bekker, A., Kaufman, A. J., Karhu, J. A., Beukes, N. J., Swart, Q. D., Coetzee, L. L. \& Eriksson, K. A. 2001 Chemostratigraphy of the Paleoproterozoic Duitschland Formation, South Africa: implications for coupled climate change and carbon cycling. Am. F. Sci. 301, 261-285.

Bekker, A., Holland, H. D., Wang, P.-L., Rumble, D. I., Stein, H. J., Hannah, J. L., Coetzee, L. L. \& Beukes, N. J. 2004 Dating the rise of atmospheric oxygen. Nature 427, 117-120. (doi:10.1038/nature02260)

Berner, R. A. 2004 The Phanerozoic carbon cycle: $\mathrm{CO}_{2}$ and $\mathrm{O}_{2}$. Oxford: Oxford University Press.

Berner, R. A., Lasaga, A. C. \& Garrels, R. M. 1983 The carbonate-silicate geochemical cycle and its effect on atmospheric carbon dioxide over the past 100 million years. Am. F. Sci. 283, 641-683.

Brocks, J. J., Logan, G. A., Buick, R. \& Summons, R. E. 1999 Archean molecular fossils and the early rise of eukaryotes. Science 285, 1033-1036. (doi:10.1126/science.285.5430. 1033)

Broecker, W. S. \& Peng, T.-H. 1982 Tracers in the sea. Palisades, NY: Eldigo Press (Lamont Doherty Geological Observatory).
Canfield, D. E. 2005 The early history of atmospheric oxygen: homage to Robert M. Garrels. Annu. Rev. Earth Planet. Sci. 33, 1-36. (doi:10.1146/annurev.earth.33. 092203.122711)

Catling, D. C., Zahnle, K. J. \& McKay, C. P. 2001 Biogenic methane, hydrogen escape, and the irreversible oxidation of early Earth. Science 293, 839-843. (doi:10.1126/ science.1061976)

Cavalier-Smith, T. 2006 Cell evolution and Earth history: stasis and revolution. Phil. Trans. R. Soc. B 361, 969-1006. (doi:10.1098/rstb.2006.1842)

Condie, K. C., DesMarais, D. J. \& Abbott, D. 2001 Precambrian superplumes and supercontinents: a record in black shales, carbon isotopes, and paleoclimates? Precambrian Res. 106, 239-260. (doi:10.1016/S03019268(00)00097-8)

Crowell, J. C. 1999 Pre-Mesozoic ice ages: their bearing on understanding the climate system. GSA Memoir 192. Boulder, CO: Geological Society of America.

DesMarais, D. J. 1998 Earth's early biosphere. Gravitational and Space Biology Bull. 11, 23-30.

Evans, D. A., Beukes, N. J. \& Kirschvink, J. L. 1997 Lowlatitude glaciation in the Palaeoproterozoic era. Nature 386, 262-266. (doi:10.1038/386262a0)

Farquhar, J. \& Wing, B. A. 2003 Multiple sulfur isotopes and the evolution of the atmosphere. Earth Planet. Sci. Lett. 213, 1-13.

Farquhar, J., Bao, H. \& Thiemans, M. 2000 Atmospheric influence of Earth's earliest sulfur cycle. Science 289, 756-758. (doi:10.1126/science.289.5480.756)

Farquhar, J., Savarino, J., Airieau, S. \& Thiemens, M. H. 2001 Observation of wavelength-sensitive mass-independent sulfur isotope effects during $\mathrm{SO}_{2}$ photolysis: application to the early atmosphere. F. Geophys. Res. 106, 1-11. (doi:10.1029/2000JE001437)

Gough, D. O. 1981 Solar interior structure and luminosity variations. Sol. Phys. 74, 21-34. (doi:10.1007/BF00151270)

Hayes, J. M. 1983 Geochemical evidence bearing on the origin of aerobiosis, a speculative hypothesis. In Earth's earliest biosphere: its origin and evolution (ed. J. W. Schopf), pp. 291-301. Princeton, NJ: Princeton University Press.

Hayes, J. M. 1994 Global methanotrophy at the ArcheanPreoterozoic transition. In Early life on Earth (ed. S. Bengtson), pp. 220-236. New York: Columbia University Press.

Hayes, J. M. \& Waldbauer, J. R. 2006 The carbon cycle and associated redox processes through time. Phil. Trans. R. Soc. B 361, 931-950. (doi:10.1098/rstb.2006.1840)

Hilburn, I. A., Kirschvink, J. L., Tajika, E., Tada, R., Hamano, Y. \& Yamamoto, S. 2005 A negative fold test on the Lorrain Formation of the Huronian Supergroup: uncertainty on the paleolatitude of the Paleoproterozoic Gowganda glaciation and implications for the great oxygenation event. Earth Planet. Sci. Lett. 232, 315-332. (doi:10.1016/j.epsl.2004.11.025)

Hoffman, P. F., Kaufman, A. J., Halverson, G. P. \& Schrag, D. P. 1998 A Neoproterozoic snowball Earth. Science 281, 1342-1346. (doi:10.1126/science.281.5381.1342)

Holland, H. D. 1984 The chemical evolution of the atmosphere and oceans. Princeton, NJ: Princeton University Press.

Holland, H. D. 1994 Early Proterozoic atmospheric change. In Early life on Earth (ed. S. Bengtson), pp. 237-244. New York: Columbia University Press.

Holland, H. D. 2002 Volcanic gases, black smokers, and the Great Oxidation Event. Geochim. Cosmochim. Acta 66, 3811-3826. (doi:10.1016/S0016-7037(02)00950-X)

Holland, H. D. 2006 The oxygenation of the atmosphere and oceans. Phil. Trans. R. Soc. B 361, 903-915. (doi:10.1098/ rstb.2006.1838) 
Holmden, C. \& Muehlenbachs, K. 1993 The ${ }^{18} \mathrm{O} /{ }^{16} \mathrm{O}$ ratio of 2-billion-year-old seawater inferred from ancient oceanic crust. Science 259, 1733-1736.

Huston, D. L. \& Logan, G. A. 2004 Barite, BIFs and bugs: evidence for the evolution of the Earth's early hydrosphere. Earth Planet. Sci. Lett. 220, 41-55. (doi:10.1016/ S0012-821X(04)00034-2)

Karhu, J. \& Epstein, S. 1986 The implication of the oxygen isotope records in coexisting cherts and phosphates. Geochim. Cosmochim. Acta 50, 1745-1756. (doi:10.1016/ 0016-7037(86)90136-5)

Kasting, J. F. 1987 Theoretical constraints on oxygen and carbon dioxide concentrations in the Precambrian atmosphere. Precambrian Res. 34, 205-229. (doi:10.1016/03019268(87)90001-5)

Kasting, J. F. 1988 Runaway and moist greenhouse atmospheres and the evolution of Earth and Venus. Icarus 74, 472-494. (doi:10.1016/0019-1035(88)90116-9)

Kasting, J. F. 1993 Earth's early atmosphere. Science 259, 920-926.

Kasting, J. F. In press. Habitable planets around the Sun and other stars. In Canary Islands Winter School (November, 2004).

Kasting, J. F. \& Brown, L. L. 1998 Setting the stage: the early atmosphere as a source of biogenic compounds. In The molecular origins of life: assembling the pieces of the puzzle (ed. A. Brack), pp. 35-56. New York: Cambridge University Press.

Kasting, J. F. \& Catling, D. 2003 Evolution of a habitable planet. Annu. Rev. Astron. Astrophys. 41, 429-463. (doi:10.1146/annurev.astro.41.071601.170049)

Kasting, J. F. \& Walker, J. C. G. 1981 Limits on oxygen concentration in the prebiological atmosphere and the rate of abiotic fixation of nitrogen. F. Geophys. Res. 86, 1147-1158.

Kasting, J. F., Zahnle, K. J. \& Walker, J. C. G. 1983 Photochemistry of methane in the Earth's early atmosphere. Precambrian Res. 20, 121-148. (doi:10.1016/03019268(83)90069-4)

Kasting, J. F., Pollack, J. B. \& Crisp, D. 1984 Effects of high $\mathrm{CO}_{2}$ levels on surface temperature and atmospheric oxidation state of the early Earth. F. Atmos. Chem. 1, 403-428. (doi:10.1007/BF00053803)

Kasting, J. F., Toon, O. B. \& Pollack, J. B. 1988 How climate evolved on the terrestrial planets. Sci. Am. 256, 90-97.

Kasting, J. F., Zahnle, K. J., Pinto, J. P. \& Young, A. T. 1989 Sulfur, ultraviolet radiation, and the early evolution of life. Orig. Life 19, 95-108. (doi:10.1007/BF01808144)

Kasting, J. F., Pavlov, A. A. \& Siefert, J. L. 2001 A coupled ecosystem-climate model for predicting the methane concentration in the Archean atmosphere. Orig. Life Evol. Biosph. 31, 271-285. (doi:10.1023/A:1010600401718)

Kelley, D. S. et al. 2001 An off-axis hydrothermal vent field near the Mid-Atlantic Ridge at $30^{\circ} \mathrm{N}$. Nature 412, 145-149. (doi:10.1038/35084000)

Kelley, D. S. et al. 2005 A serpentinite-hosted ecosystem: the Lost City hydrothermal vent field. Science 307, 1428-1434. (doi:10.1126/science.1102556)

Kharecha, P., Kasting, J. F. \& Siefert, J. L. 2005 A coupled atmosphere-ecosystem model of the Early Archean Earth. Geobiology 3, 53-76. (doi:10.1111/j.1472-4669.2005. 00049.x)

Kiehl, J. T. \& Dickinson, R. E. 1987 A study of the radiative effects of enhanced atmospheric $\mathrm{CO}_{2}$ and $\mathrm{CH}_{4}$ on early Earth surface temperatures. f. Geophys. Res. 92, 2991-2998.

Kirschvink, J. L. 1992 Late Proterozoic low-latitude global glaciation: the snowball Earth. In The Proterozoic biosphere: a multidisciplinary study (ed. J. W. Schopf \& C. Klein), pp. 51-52. New York: Cambridge University Press.
Kirshvink, J. L., Gaidos, E. J., Bertaini, L. E., Beukes, N. J., Gutzmer, J., Maepa, L. N. \& Steinberger, R. E. 2000 Paleoproterozoic snowball Earth: extreme climatic and geochemical global change and its biological consequences. Proc. Natl Acad. Sci. USA 97, 1400-1405. (doi:10.1073/pnas.97.4.1400)

Knauth, L. P. \& Epstein, S. 1976 Hydrogen and oxygen isotope ratios in nodular and bedded cherts. Geochim. Cosmochim. Acta 40, 1095-1108. (doi:10.1016/00167037(76)90051-X)

Knauth, P. \& Lowe, D. R. 2003 High Archean climatic temperature inferred from oxygen isotope geochemistry of cherts in the $3.5 \mathrm{Ga}$ Swaziland Supergroup, South Africa. GSA Bull. 115, 566-580.

Kopp, R. E., Kirshvink, J. L., Hilburn, I. \& Nash, C. Z. 2005 The Paleoproterozoic snowball Earth: a climate disaster triggered by the evolution of photosynthesis. Proc. Natl Acad. Sci. USA 102, 11 131-11 136. (doi:10.1073/pnas. 0504878102)

Kral, T. A., Brink, K. M., Miller, S. L. \& McKay, C. P. 1998 Hydrogen consumption by methanogens on the early Earth. Orig. Life Evol. Biosph. 28, 311-319. (doi:10.1023/ A: 1006552412928)

Lecuyer, C. \& Ricard, Y. 1999 Long-term fluxes and budget of ferric iron: implication for the redox states of the Earth's mantle and atmosphere. Earth Planet. Sci. Lett. 165, 197-211. (doi:10.1016/S0012-821X(98)00267-2)

Matsui, T. \& Abe, Y. $1986 a$ Evolution of an impact-induced atmosphere and magma ocean on the accreting Earth. Nature 319, 303-305. (doi:10.1038/319303a0)

Matsui, T. \& Abe, Y. $1986 \mathrm{~b}$ Impact-induced atmospheres and oceans on Earth and Venus. Nature 322, 526-528. (doi:10. 1038/322526a0)

Mojzsis, S. J., Coath, C. D., Greenwood, J. P., McKeegan, K. D. \& Harrison, T. M. 2003 Mass-independent isotope effects in Archean (2.5-3.8 Ga) sedimentary sulfides determined by ion microprobe analysis. Geochim. Cosmochim. Acta 67, 1635-1658.

Muehlenbachs, K. \& Clayton, R. N. 1976 Oxygen isotope composition of the oceanic crust and its bearing on seawater. F. Geophys. Res. 81, 4365-4369.

Nisbet, E. G., Bickle, M. J., Martin, A. \& Orpen, J. L. 1993 Sedimentology of the Brooklands Formation, Zimbabwe: development of an Archaean greenstone belt in a rifted graben. In The geology of the Belingwe Greenstone Belt, Zimbabwe (ed. M. J. Bickle \& E. G. Nisbet), pp. 87-120. Rotterdam: A. A. Balkema.

Ono, S., Eigenbrode, J. L., Pavlov, A. A., Kharecha, P., Rumble, D., Kasting, J. F. \& Freeman, K. H. 2003 New insights into Archean sulfur cycle from mass-independent sulfur isotope records from the Hamersley Basin, Australia. Earth Planet. Sci. Lett. 213, 15-30. (doi:10. 1016/S0012-821X(03)00295-4)

Ono, S., Beukes, N., Rumble, D. \& Fogel, M. In press. Early evolution of atmospheric oxygen from multiple-sulfur and carbon isotope records of the $2.9 \mathrm{Ga}$ Pongola Supergroup, Southern Africa. S. Afr. F. Geol.

Pavlov, A. A. \& Kasting, J. F. 2002 Mass-independent fractionation of sulfur isotopes in Archean sediments: strong evidence for an anoxic Archean atmosphere. Astrobiology 2, 27-41. (doi:10.1089/153110702753621321)

Pavlov, A. A., Kasting, J. F., Brown, L. L., Rages, K. A. \& Freedman, R. 2000 Greenhouse warming by $\mathrm{CH}_{4}$ in the atmosphere of early Earth. f. Geophys. Res. 105, 11 981-11 990. (doi:10.1029/1999JE001134)

Pavlov, A. A., Kasting, J. F. \& Brown, L. L. 2001 UVshielding of $\mathrm{NH}_{3}$ and $\mathrm{O}_{2}$ by organic hazes in the Archean atmosphere. F. Geophys. Res. 106, 23 267-23 287. (doi:10. 1029/2000JE001448) 
Pavlov, A. A., Hurtgen, M. T., Kasting, J. F. \& Arthur, M. A. 2003 Methane-rich Proterozoic atmosphere? Geology 31, 87-90. (doi:10.1130/0091-7613(2003)031< 0087:MRPA > 2.0.CO;2)

Perry, E. C. \& Lefticariu, L. 2003 Formation and geochemistry of Precambrian chert. In Treatise on Geochemistry. vol.7, Sediments, diagenesis, and sedimentary rocks (ed. $\mathrm{H}$. Holland \& K. Turekian). McKenzie, F.T.: Elsevier.

Pinto, J. P., Gladstone, C. R. \& Yung, Y. L. 1980 Photochemical production of formaldehyde in the Earth's primitive atmosphere. Science 210, 183-185.

Roscoe, S. M. 1969 Huronian rocks and uraniferous conglomerates in the Canadian Shield. Geol. Surv. Can. Pap. 68-40.

Roscoe, S. M. 1973 The Huronian Supergroup: a Paleophebian succession showing evidence of atmospheric evolution. Geol. Soc. Can. Spec. Pap. 12, 31-48.

Rye, R., Kuo, P. H. \& Holland, H. D. 1995 Atmospheric carbon dioxide concentrations before 2.2 billion years ago. Nature 378, 603-605. (doi:10.1038/378603a0)

Sagan, C. \& Mullen, G. 1972 Earth and Mars: evolution of atmospheres and surface temperatures. Science 177, 52-56.

Shen, Y. \& Buick, R. 2004 The antiquity of microbial sulfate reduction. Earth Sci. Rev. 64, 243-272. (doi:10.1016/ S0012-8252(03)00054-0)

Shen, Y., Buick, R. \& Canfield, D. E. 2001 Isotopic evidence for microbial sulfate reduction in the Early Archean era. Nature 410, 77-81. (doi:10.1038/35065071)

Shields, G. \& Veizer, J. 2002 Precambrian marine carbon isotope database: version 1.1. Geochem. Geophys. Geosyst. 3. (doi:10.1029/2001GC000266) http:/gcubedorg/gc2002/ $2001 \mathrm{GC} 000266$.

Skyring, T. W. \& Donnelly, T. H. 1982 Precambrian sulfur isotopes and a possible role for sulfite in the evolution of bacterial sulfate reduction. Precambrian Res. 17, 41-61.

Sleep, N. H. \& Hessler, A. M. 2006 Weathering of quartz as an Archean climate indicator. Earth Planet. Sci. Lett. 241, 594-602.

Sleep, N. H., Zahnle, K. J., Kasting, J. F. \& Morowitz, H. J. 1989 Annihilation of ecosystems by large asteroid impacts on the early Earth. Nature 342, 139-142. (doi:10.1038/ 342139a0)

Summons, J. R., Jahnke, L. L., Hope, J. M. \& Logan, G. A. 1999 Nature 400, 554-557. (doi:10.1038/23005)
Tian, F., Toon, O. B., Pavlov, A. A. \& De Sterck, H. 2005 A hydrogen rich early Earth atmosphere. Science 308, 1014-1017. (doi:10.1126/science.1106983)

Valley, J. W., Peck, W. H., King, E. M. \& Wilde, S. A. 2002 A cool early Earth. Geology 30, 351-354. (doi:10.1130/ 0091-7613(2002)030<0351:ACEE > 2.0.CO;2)

Walker, J. C. G. 1977 Evolution of the atmosphere. New York: Macmillan.

Walker, J. C. G. 1987 Was the Archaean biosphere upsidedown? Nature 329, 710-712. (doi:10.1038/329710a0)

Walker, J. C. G. \& Lohmann, K. C. 1989 Why the oxygen isotopic composition of seawater changes with time. Geophys. Res. Lett. 16, 323-326.

Walker, J. C. G., Hays, P. B. \& Kasting, J. F. 1981 A negative feedback mechanism for the long-term stabilization of Earth's surface temperature. F. Geophys. Res. 86, 9776-9782.

Walker, J. C. G., Klein, C., Schidlowski, M., Schopf, J. W., Stevenson, D. J. \& Walter, M. R. 1983 Environmental evolution of the Archean-Early Proterozoic Earth. In Earth's earliest biosphere (ed. J. W. Schopf), pp. 260-290. Princeton, NJ: Princeton University Press.

Wallmann, K. 2004 Impact of atmospheric $\mathrm{CO}_{2}$ and galactic cosmic radiation on Phanerozoic climate change and the marine delta ${ }^{18}$-O record. Geochem. Geophys. Geosyst. 5. (doi:10.1029/2003G000683) (Q06004)

Watanabe, Y., Ikemi, H. \& Ohmoto, H. 2005 Implications of the absence of mass independent sulfur isotope fractionation in 2.76-Ga lacustrine and 3.0-Ga marine sediments. Abstracts of early Earth symposium, Tokyo, May.

Wilde, S. A., Valley, J. W., Peck, W. H. \& Graham, C. M. 2001 Evidence from detrital zircons for the existence of continental crust and oceans on Earth 4.4 Gyr ago. Nature 409, 175-178. (doi:10.1038/35051550)

Wing, B. A. et al. $2002 \Delta^{33} \mathrm{~S}, \delta^{34} \mathrm{~S}$ and $\delta^{13} \mathrm{C}$ constraints on the Paleoproterozoic atmosphere during the Huronian glaciation. Geochim. Cosmochim. Acta 66, A840.

Young, G. M. 1991 Annual Meeting, Toronto, 1991, Field Trip B5, Guidebook. Toronto: Geological Association of Canada.

Young, G. M., von Brunn, V., Gold, D. J. C. \& Minter, W. E. L. 1998 Earth's oldest reported glaciation: physical and chemical evidence from the Archean Mozaan Group $(\sim 2.9 \mathrm{Ga})$ of South Africa. F. Geol. 106, 523-538.

Zahnle, K. J., Kasting, J. F. \& Pollack, J. B. 1988 Evolution of a steam atmosphere during Earth's accretion. Icarus 74, 62-97. (doi:10.1016/0019-1035(88)90031-0) 